\title{
UJI COBA MESIN PENGERING KAYU KOMBINASI TENAGA SURYA DAN PANAS DARI TUNGKU TIPE I
}

\author{
(Trial on Wood-drying Machine Powered by the Combined Solar \\ Energy and Type-I Heating-Stove)
}

\author{
Oleh/By : \\ Efrida Basri \& Achmad Supriadi ${ }^{1)}$
}

\begin{abstract}
Technical and financial feasibility of a combined solar energy and heating stove (SC+TI) wood drying machine has been recently assessed. The machine batch had a capacity of $19 \mathrm{~m}^{3}$ and was located in a wood craft industry in Ngaringan Village, Grobogan Sub Regency, Central Java.

Assessment was carried out during the use of the machine for drying teak wood (Tectona grandis L.f.). During the day, the heat source was from solar energy. At night or depending on the need, the heat was provided by heating stove with biomass or wood waste as the fuel. The study purpose was to analysis technical and financial feasibility of the drying unit.

Results showed that average temperature achieved inside the drying chamber ranged from 40 to $50^{\circ} \mathrm{C}$. However the optimal condition for drying teak wood was around $45-70^{\circ} \mathrm{C}$. Thus, additional heat was indused from the stove.

The time required to dry wood with initial moisture content of $50 \%$ to final moisture content of $10 \%$ was averaged 13 days. The annual drying yield was around $80 \%$ or about $304 \mathrm{~m}^{3}$. The need of wood waste for heating stove was 8 $\mathrm{m}^{3} /$ drying period.

Invesment required for constructing on unit of the wood drying chamber is about $\mathrm{R} p 74,635,000$. Annual production cost for producing of $304 \mathrm{~m}^{3}$ was $\mathrm{Rp} 3,251,548,750$ with manufacturing cost of $\mathrm{Rp} 10,695,884 / \mathrm{m}^{3}$. The financial feasibility analysis showed that with price of dried jati $\mathrm{Rp} 11,000,000 / \mathrm{m}^{3}, \mathrm{BEP}$ (Break Event Point) at 86,3 $m^{3}$, NPV (Net Present Value) Rp 374,245,458 and IRR (Internal Rate of Return) 80\%. This result indicates that the operation of drying-unit is technically and economically feasible.
\end{abstract}

Keywords: Drying machine, solar energy, type-I heating-stove, wood waste, teak, technical and financial feasibility

\begin{abstract}
ABSTRAK
Telah dilakukan uji coba teknis dan finansial terhadap mesin pengeringan kayu kombinasi tenaga surya dan panas dari tungku tipe SC+TI untuk kapasitas $19 \mathrm{~m}^{3}$ di salah satu industri/pengrajin kayu di Ngaringan, Grobogan, Jawa Tengah. Uji coba dilakukan terhadap kayu jati (Tectona grandis L.f.). Kebutuhan panas pengeringan di siang hari diperoleh dari tenaga surya dan di malam hari atau
\end{abstract}

${ }^{1}$ Peneliti pada Pusat Penelitian dan Pengembangan Hasil Hutan, Bogor 
tergantung kebutuhan diperoleh dari tungku pembakaran dengan bahan bakar biomas/limbah kayu dari penggergajian sendiri. Tujuan uji coba adalah untuk mengetahui kelayakan teknis dan finansial dari pemanfaatan masin pengering tersebut.

Hasil uji coba menunjukan suhu rata-rata harian dari panas surya yang diterima ruang pengering berkisar antara $40-50^{\circ} \mathrm{C}$, sementara suhu untuk pengeringan kayu jati berkisar antara $45-70^{\circ} \mathrm{C}$. Kekurangan panas diperoleh dari tungku bakar. Untuk mengeringkan sortimen kayu dengan kadar air 50\% sampai mencapai kadar air 10\% memerlukan waktu rata-rata 13 hari dan menghasilkan rendemen kayu kering sekitar $80 \%$. Konsumsi limbah kayu untuk bahan bakar tungku pada setiap periode pengeringan $8 \mathrm{~m}^{3}$.

Investasi pendirian unit pengeringan memerlukan biaya sebesar Rp 74.635.000. Biaya produksi setahun (jumlah produksi $304 \mathrm{~m}^{3}$ ) adalah Rp 3.251.548.750, sehingga harga pokok produk Rp $10.695 .884 / \mathrm{m}^{3}$. Analisis kelayakan finansial pemanfaatan mesin pengering menunjukan dengan harga jual kayu jati kering Rp $11.000 .000 / \mathrm{m}^{3}$. Titik impas (BEP) tercapai pada produksi sebesar $86,3 \mathrm{~m}^{3}$, Nilai sekarang neto (NPV) Rp + 374.245.458 dan Internal Rate of Return (IRR) 80\%. Hasil ini menunjukkan bahwa mesin pengering tersebut layak untuk dioperasikan.

Kata kunci : Mesin pengering, tenaga surya, tungku tipe I, limbah kayu, jati, kelayakan teknis dan finansial

\section{PENDAHULUAN}

Dalam industri perkayuan, kualitas menjadi faktor penentu, apalagi jika tujuannya untuk ekspor yang menuntut produk berkualitas tinggi. Jika persyaratan kualitas tidak sesuai harapan, maka produkpun dikembalikan disertai dengan sangsi. Salah satu faktor yang menentukan kualitas produk dari bahan baku kayu adalah tingkat kekeringannya.

Selama ini ekspor produk kayu dari sektor usaha kecil-menengah (UKM), terutama ke negara empat musim banyak yang terganjal atau dikembalikan lagi karena kualitasnya kurang memenuhi persyaratan yang diminta. Produk kayu tersebut banyak yang retak, pecah, berubah bentuk, dan terserang jamur, sehingga warna permukaannya menjadi tidak seragam (discoloration). Hal ini disebabkan kadar airnya masih tinggi.

Problem pengeringan yang dihadapi industri kecil saat ini adalah belum tersedianya mesin pengering kayu yang mudah diaplikasikan dan dengan harga terjangkau. Mesin pengering kayu yang dipasarkan saat ini selain harganya sangat mahal karena sebagian besar komponennya diimpor dari luar, juga dibuat untuk memenuhi kapasitas industri besar. Jika dipaksakan untuk diterapkan di UKM yang volume bahan baku dan modal yang terbatas, maka biaya produksi menjadi sangat tinggi.

Salah satu mesin pengering kayu yang sesuai untuk pengrajin/industri pengolahan kayu skala UKM adalah prototipe sistem kombinasi tenaga surya dan panas dari tungku bakar dengan bahan bakar berupa sebetan yang dihasilkan dari limbah penggergajian (tungku Tipe I) atau minyak tanah/solar (tungku Tipe II) yang didisain oleh Pusat Penelitian dan Pengembangan Hasil Hutan Bogor. Sistem pengeringan dengan metode ini sangat hemat biaya karena dapat memanfaatkan tenaga surya pada siang hari yang rata-rata jatuh di Indonesia sejumlah 0,9 x 1018 KJ (Kilo Joule)/tahun (Abdullah, 1991), sementara. penggunaan tungku bakar disesuaikan dengan kebutuhan. 
Sumber panas pada siang hari memanfaatkan energi surya yang masuk melewati atap dari bahan transparan dan diserap oleh pengumpul panas berupa lembaran seng bercat hitam yang dipasang di bawah atap. Berdasarkan hasil penelitian Chandra (1996) dan Abdullah (2003), bahan pengumpul panas yang dicat hitam berefek terhadap kenaikan tingkat suhu dan penurunan tingkat kelembaban. Menurut Howe (1977) dan Armstrong (2005), panas radiasi yang tinggi dari matahari hanya bisa terjadi bila melewati bidang dari bahan yang transparan, seperti kaca, fiberglass atau plastik. Namun menurut Williams (1977), dari semua bahan transparan, kaca lebih efektif mengurangi kehilangan panas yang dipantulkan kembali oleh pengumpul panas (solar collector).

Pemanfaatan limbah penggergajian yang tidak dapat dimanfaatkan lagi untuk bahan bakar tungku selain bisa menghemat biaya juga dapat membersihkan lingkungan. Salah satu problem yang dihadapi industri penggergajian di Indonesia saat ini adalah dalam mengatasi limbah. Setiap tahun jumlah limbah yang dihasilkan sekitar 7,8 juta $\mathrm{m}^{3}$ (Idris, 1995 dalam Roliadi dan Pasaribu, 2005; Anonim, 1997/1998).

Pada laporan ini dikemukakan hasil penelitian "uji coba mesin pengering kayu kombinasi tenaga surya dan panas dari tungku tipe I (SC+TI)" berkapasitas kayu basah \pm 19 $\mathrm{m} 3$, dalam rangka meningkatkan nilai tambah bahan baku kayu dan menghemat biaya produksi.

\section{BAHAN DAN METODE}

\section{A. Bahan dan Peralatan}

Kayu yang diujicobakan adalah kayu jati (Tectona grandis) yang merupakan bahan baku utama sebagian besar industri/pengrajin kayu di Kabupaten Grobogan, Jawa Tengah. Peralatan utama yang digunakan adalah mesin pengering kombinasi tenaga surya dengan tungku Tipe I (SC+TI) \{Gambar 1\}. Bangunan pengeringan dan tungku tersebut dibuat pada tahun 2004 di salah satu industri/pengrajin kayu di Desa Ngaringan, Kab. Grobogan, Jawa Tengah. Ukuran bangunan pengeringan tenaga surya untuk kapasitas $19 \mathrm{~m}^{3}$ adalah panjang 10,0 m; lebar 3,5 m; tinggi bangunan depan 2,9 m dan bangunan belakang 3,3 m. Pengambilan data dilakukan pada tahun 2005/2006.

Sumber panas pada siang hari memanfaatkan energi surya dan pada malam hari atau tergantung kebutuhan, berasal dari tungku bakar dengan bahan bakar limbah dari penggergajian kayu milik sendiri, berupa kulit, sebetan dan potongan ujung dolok yang tidak bisa dimanfaatkan lagi. Dengan bantuan blower pendorong yang berkekuatan motor 1,5 HP (tenaga kuda), udara panas dari tungku langsung dialirkan ke dalam ruang pengering. Aliran panas, baik yang datang dari matahari maupun yang datang dari tungku akan didistribusikan secara merata oleh 3 buah kipas ( $f a n)$, masing-masing berdaya 3 HP ke setiap bagian permukaan kayu. Kelembaban dalam bangunan pengeringan dapat dikurangi dengan menggunakan 2 buah kipas pembuang (exhaust fan) dengan kekuatan 3/4 HP. Peralatan penunjang yang digunakan antara lain: oven memmert, timbangan digital, dial caliper, penggaris, alat pengukur kadar air (moisture meter) dan gergaji mesin. 


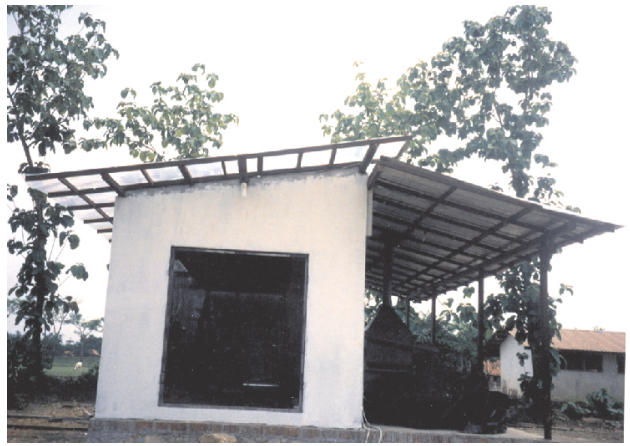

A. Bangunan pengeringan dengan radiasi panas matahari melalui atap (Drying building with solar radiation passing through the roof)

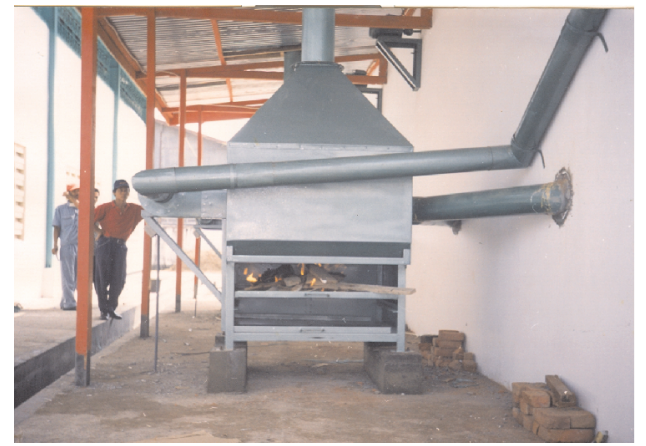

B. Tungku bakar untuk pemakaian bahan bakar limbah kayu/biomas (Stove that uses wood waste/biomass as fuel)

Gambar1. Mesin pengeringan kombinasi tenaga surya dan tungku tipe I (SC+TI)

Figure 1. Drying machine with the combined use solar energy and type-I beating stove $(S C+T I)$

\section{B. Metode}

Prosedur penelitian, sebagai berikut:

\section{Penetapan bagan pengeringan}

Penelitian untuk mendapatkan bagan pengeringan kayu jati dilakukan di laboratorium Pengeringan Kayu Pusat Penelitian dan Pengembangan Hasil Hutan, Bogor. Penelitian diawali dengan penetapan kadar air awal dan pengujian sifat pengeringan. Contoh uji sebanyak 10 buah dibuat dengan ukuran 2,5 cm (tebal) x $10 \mathrm{~cm}$ (lebar) x $20 \mathrm{~cm}$ (panjang) dan dikeringkan dalam oven pada suhu 100C (konstan) sampai mencapai kadar air 1\%. Berdasarkan jenis cacat dan jumlahnya kemudian dibuat klasifikasi mutu yang mengacu pada standar Jepang (Terazawa,1965 dalam Basri dan Hajib, 2004). Penetapan berat jenis (BJ) dan pengujian nilai penyusutan kayu pada arah radial (R) dan tangensial (T) juga dilakukan, sesuai standar ASTM D 143-94 (Anonim, 1994). Dari data klasifikasi mutu serta data BJ dan rasio penyusutan tangensial ( $T$ ) terhadap radial $(R)$ atau $T / R$, kemudian ditetapkan bagan pengeringan untuk kayu tersebut.

\section{Uji coba pengeringan}

Uji coba pengeringan dilakukan dengan berpegangan pada bagan yang diperoleh dari hasil percobaan laboratorium. Kayu jati untuk percobaan dibuat dalam bentuk papan $\pm 4 \mathrm{~cm}$ (t) x 20 - $25 \mathrm{~cm}$ (l) dan 200-225 cm (p), disesuaikan dengan ukuran produk yang akan dibuat pengrajin. Volume kayu yang dikeringkan untuk setiap periode pengeringan $19 \mathrm{~m}^{3}$ yang terbagi menjadi 4 tumpukan ke arah memanjang bangunan. Sortimen kayu yang dikeringkan disusun secara horizontal menggunakan ganjal setebal $3 \mathrm{~cm}$ dan jarak antar ganjal $75 \mathrm{~cm}$. 
Contoh uji untuk pengamatan diukur kadar airnya secara berkala dengan alat ukur moisture meter dari setiap tumpukan di bagian atas, tengah dan bawah tumpukan. Agar udara panas dapat sampai ke tumpukan kayu paling bawah dan terdistribusi secara merata ke seluruh bagian kayu, maka antara lantai ke kayu diberi ganjal pembatas setinggi $12 \mathrm{~cm}$ dan ada ruang kosong antara kayu dengan dinding dan langit-langit ruang pengering.

\section{Pengumpulan data terkait dengan uji coba}

Data terkait mencakup data aspek teknis dan data aspek finansial/ekonomis. Data aspek teknis, terutama adalah hasil uji coba pengeringan dengan mesin SC+TI (Gambar 1) menggunakan bagan dari percobaan laboratorium, antara lain mutu kayu kering, lama/waktu pengeringan, rendemen kayu kering tanpa kerusakan, kebutuhan bahan bakar tungku dan listrik. Sedangkan data aspek finansial meliputi biaya investasi, biaya produksi, dan harga jual kayu gergajian kering per $\mathrm{m}^{3}$.

\section{Analisis Data}

Data teknis hasil uji coba digunakan untuk evaluasi kelayakan teknis mesin pengering SC+TI, sedangkan data finansial/ekonomi terhadap mesin pengering SC+TI dilakukan untuk evaluasi kelayakan alat bila mengoperasikan alat tersebut (Candra, 1996). Kelayakan finansial mencakup antara lain biaya investasi, biaya produksi dan harga pokok, proyeksi pendapatan, titik impas (break-even point/BEP), Net Present Value (NPV) dan Internal Rate of Return (IRR). Break Even Point, Net Present Value dan Internal rate of Return dihitung menggunakan rumus (Riyanto, 2005):

$$
\begin{aligned}
& \mathrm{BEP} \text { (unit) }=\frac{\mathrm{FC}}{\mathrm{P} / \mathrm{u}-\mathrm{VC} / \mathrm{u}} \mathrm{BEP}(\mathrm{Rp})=\frac{\mathrm{FC}}{1-\mathrm{TVC} / \mathrm{TS}} \\
& \mathrm{NPV}=\sum_{\mathrm{t}=0}^{\mathrm{n}} \frac{\mathrm{At}}{(1+\mathrm{k})^{\mathrm{t}}} \\
& \operatorname{IRR}(\%)=\mathrm{P}_{1}-\mathrm{C}_{1} \frac{\mathrm{P}_{2}-\mathrm{P}_{1}}{\mathrm{C}_{2}-\mathrm{C}_{1}}
\end{aligned}
$$

Dimana :

$\mathrm{FC} \quad=$ Biaya tetap (Fixed cost)

$\mathrm{P} / \mathrm{u}=$ Harga jual per unit (Price/unit)

$\mathrm{VC} / \mathrm{u}=$ Biaya variabel per unit (Variable cost/ unit)

TVC = Total biaya variabel (Total Variable cost)

TS = Total penjualan (Total sales)

$\mathrm{P}_{1} \quad=$ Tingkat bunga ke 1

$\mathrm{P}_{2}=$ Tingkat bunga ke 2

$\mathrm{C}_{1}=\mathrm{NPV}$ (Netpresentvalue) ke 1

$\mathrm{C}_{2}=\mathrm{NPV}$ (Netpresentvalue) ke 2 


\section{HASIL DAN PEMBAHASAN}

\section{A. Kelayakan Teknis}

Hasil pengujian menunjukkan BJ kayu jati yang diujicoba bervariasi antara 0,57 - 0,70, sedangkan penyusutan rata-rata sampai kering oven 3,1 \% pada arah radial (R) dan 5,8 \% (T) arah tangensial (rasio $\mathrm{T} / \mathrm{R}<2$ ). Ini menunjukkan kayu tersebut cukup stabil. Berdasarkan hasil pengujian sifat pengeringan dan kualitas bahan baku, maka diperoleh 2 bagan pengeringan untuk kayu jati. Bagan keras (Tabel 1) untuk kayu berkualitas prima (masak tebang) yang diambil dari bagian pangkal dan tengah pohon, sedangkan bagan lunak (Tabel 2) untuk kayu kualitas campuran, termasuk kayu hasil penjarangan. Karena bahan baku kayu jati yang tersedia di industri dari berbagai kualitas, maka bagan pengeringan yang digunakan adalah bagan lunak.

Tabel1. Bagan keras untuk pengeringan kayu jati

Table 1. Strong scbedule for drying jati wood

\begin{tabular}{|c|c|c|}
\hline $\begin{array}{c}\text { Kadar air } \\
\text { (Moisture content), \% }\end{array}$ & $\begin{array}{c}\text { Suhu } \\
\text { (Temperature), }{ }^{\circ} \mathrm{C}\end{array}$ & $\begin{array}{c}\text { Kelembaban } \\
\text { (Humidity), \% }\end{array}$ \\
\hline Basah (Green) -40 & 50 & 78 \\
$40-30$ & 60 & 73 \\
$30-25$ & 65 & 60 \\
$25-20$ & 70 & 52 \\
$20-15$ & 75 & 43 \\
$<15$ & 80 & 33 \\
\hline
\end{tabular}

Tabel 2. Bagan lunak untuk pengeringan kayu jati

Table 2. Mild schedule for drying jati wood

\begin{tabular}{|c|c|c|}
\hline $\begin{array}{c}\text { Kadar air } \\
\text { (Moisture content), \% }\end{array}$ & $\begin{array}{c}\text { Suhu } \\
\text { (Temperature), }{ }^{\circ} \mathrm{C}\end{array}$ & $\begin{array}{c}\text { Kelembaban } \\
\text { (Humidity), } \%\end{array}$ \\
\hline Basah $($ Green) -50 & 45 & 78 \\
$50-40$ & 50 & 73 \\
$40-30$ & 50 & 63 \\
$30-20$ & 60 & 56 \\
$20-15$ & 65 & 45 \\
$<15$ & 70 & 37 \\
\hline
\end{tabular}

Tungku pembakaran baru dinyalakan secara efektif ketika kadar air kayu sudah mencapai 30\%. Pada awal pengeringan, pemanasan terhadap kayu lebih banyak mengandalkan panas surya, yang rata-rata suhu hariannya berkisar antara $40-50^{\circ} \mathrm{C}$. Nilai yang diperoleh lebih rendah dari nilai yang terukur pada bangunan pengeringan tenaga surya untuk kapasitas $2 \mathrm{~m}^{3}-6 \mathrm{~m}^{3}$, yang bisa mencapai suhu $63^{\circ} \mathrm{C}$ (Basri et al., 2003). Hal ini mungkin disebabkan bangunan pengeringan tenaga surya yang diuji cobakan bahan atapnya terbuat dari fiberglass 
bukan dari kaca sebagaimana bahan atap untuk bangunan kapasitas $2 \mathrm{~m}^{3}-6 \mathrm{~m}^{3}$, yang menurut Williams (1977), lebih banyak memantulkan panas yang diterima dibandingkan dengan bahan kaca. Kemungkinan lain karena ruangannya terlalu besar, sehingga panas banyak yang hilang sebelum sampai ke permukaan kayu. Hal ini mengacu pada penelitian Duffie dan Beckman (1980 dalam Candra 1996) dan Abdullah (2003), bahwa besarnya suhu yang datang dari pengumpul panas selain ditentukan oleh intensitas radiasi surya juga oleh jarak yang ditempuh panas ke permukaan bahan yang dipanaskan. Oleh karena itu semakin luas bangunan pengering, terutama dari tinggi ruangannya, semakin sedikit panas yang diterima.

Pemakaian kayu bakar untuk setiap periode pengeringan rata-rata $0,6 \mathrm{~m}^{3} /$ hari, sehingga dalam 1 tahun membutuhkan $156 \mathrm{~m}^{3}$ limbah kayu. Kayu bakar tidak dibeli karena setiap hari dari kegiatan pengolahan kayu dihasilkan 1-2 $\mathrm{m}^{3}$ limbah yang tidak termanfaatkan. Biaya listrik untuk kegiatan pengeringan diperhitungkan dari selisih pengeluaran listrik untuk seluruh kegiatan industri setelah adanya mesin pengeringan dengan pengeluaran sebelum adanya mesin pengering.

Hasil yang diperoleh dari percobaan ini adalah kadar air awal berkisar antara 45-55\% (rata-rata 50\%). Lamanya pengeringan untuk mendapatkan kadar air 10\% berkisar antara 12 sampai 14 hari (rata-rata 13 hari). Setiap bulan dilakukan 2 kali kegiatan pengeringan, sehingga dalam 1 tahun (10 bulan efektif operasional pengeringan) jumlah kayu yang dikeringkan 380 $\mathrm{m}^{3}$. Rendemen kayu kering (setelah diperhitungkan penyusutan, cacat bentuk pecah ujung, dll) diperkirakan $80 \%$, yaitu $304 \mathrm{~m}^{3}$. Data yang diuji merupakan rata-rata dari hasil pengamatan selama 2 kali percobaan. Data rendemen sebesar $80 \%$ atau $304 \mathrm{~m}^{3}$, bukan berarti yang tersisa $20 \%$ atau $76 \mathrm{~m}^{3}$ tidak bisa digunakan lagi, tapi dijadikan sortimen yang lebih pendek/sempit untuk keperluan bahan baku produk yang sesuai dengan ukuran sortimen tersebut.

\section{B. Kelayakan Finansial}

\section{Investasi}

Investasi yang diperlukan untuk membangun satu unit mesin pengering kayu kombinasi tenaga surya dan panas dari tungkutipe I (SC+TI) adalah sebesar Rp 74.635.000 (Tabel 3). Investasi ini meliputi pengadaan bangunan pengering tenaga surya, 2 unit tungku bakar, 3 unit kipas dan berbagai peralatan penunjang.

\section{Biaya dan harga pokok produksi kayu kering}

Biaya produksi kayu kering meliputi biaya tetap dan biaya tidak tetap (variabel). Perhitungan biaya produksi sangat tergantng pada hasil penelitan aspek teknis, harga/biaya satuan yang berlaku dan asumsi-asumsi yang digunakan, yaitu sebagai berikut:
a. Harga kayu jati gergajian basah Rp $8.000 .000 / \mathrm{m}^{3}$;
b. Pemakaian limbah Rp $25.000 / \mathrm{m}^{3}$
c. Biaya listrik Rp 500.000/bln
d. Sewa tanah Rp 1.000.000/th
e. Biaya pemeliharaan alat (10\% dari harga tungku dan kipas) yaitu Rp 4.490.000;
f. Biaya penyusutan bangunan dan mesin Rp 7.463.500/tahun selama 10 tahun,
g. Suku bunga bank $15 \% /$ tahun 
Tabel3. Biaya investasi pembangunan unit mesin pengering tipe-I (SC+TI) Table 3. Investment cost for constructing the drying macbine unit of the type-I $(S C+T I)$

\begin{tabular}{|c|c|c|}
\hline No. & Perincian (Description) & Biaya $(\operatorname{Cos} t), \mathrm{Rp}$ \\
\hline 1 & Bangunan pengering tenaga surya (solar drying building) & 15.000 .000 \\
\hline 2. & $\begin{array}{l}2 \text { unit tungku bakar dilengkapi dengan blower, cerobong } \\
\text { asap dan pipa-pipa pembuangan udara basah } \\
\text { ( } 2 \text { beating stoves equipped with blower, chimney and pipes for } \\
\text { driving out wet air) }\end{array}$ & 35.000 .000 \\
\hline 3 & $\begin{array}{l}3 \text { unit kipas untuk mendistribusi panas } \\
\text { ( } 3 \text { in air-in take fans for distributing beat) }\end{array}$ & 7.500 .000 \\
\hline 4. & $\begin{array}{l}2 \text { unit kipas untuk membuang udara basah } \\
\text { (2 exhaust fans for driving out wet air) }\end{array}$ & 2.400 .000 \\
\hline \multirow[t]{3}{*}{5.} & $\begin{array}{l}\text { Peralatan penunjang lainnya, antara lain (Other auxilliary } \\
\text { equipment, among others); MCB (Mini Circuit Breaker), kontaktor } \\
\text { (contactor), kabel (electrical cable), termometer (thermometer) }\end{array}$ & 5.000 .000 \\
\hline & $\begin{array}{l}\text { Jumlah (Sub total) } \\
\text { Tidak terduga (Unpredictable), 15\% Overa }\end{array}$ & $\begin{array}{r}64.900 .000 \\
9 \quad .735 .000 \\
\end{array}$ \\
\hline & Jumlah keseluruhan (Overall total) & 74.635 .000 \\
\hline
\end{tabular}

Keterangan (Remarks): Rp = Rupiah (Indonesian currency)

Selain itu, kegiatan pengeringan terpadu dengan kegiatan penggergajian dan pengerjaan kayu, sehingga pengeluaran biaya untuk kelengkapan kantor, bangunan kantor dan gaji selain operator pengeringan tidak dimasukan dalam perhitungan biaya.

Dengan mengacu pada aspek teknis dan informasi biaya/harga, dihitung seluruh biaya yang terjadi. Untuk menghasilkan $304 \mathrm{~m}^{3}$ kayu kering (dalam ujicoba ini digunakan kayu jati) dibutuhkan biaya produksi sebesar Rp 3.251.548.750, sehingga harga pokok produksi kayu kering jati per $\mathrm{m}^{3}$ adalah sebesar $\mathrm{Rp}$ 10.695.884. Rincian biaya dan harga pokok produksi disajikan pada Tabel 4.

\section{Proyeksi pendapatan}

Harga jual sortimen kayu jati yang sudah dikeringkan diasumsikan minimal Rp $11.000 .000 / \mathrm{m}^{3}$. Hal ini mengacu pada perbedaan harga jual kayu kering yang diperdagangkan, umumnya berkisar antara 40 - 70\% lebih mahal dari harga kayu basahnya. Harga pembelian sortimen kayu jati yang belum dikeringkan (kayu basah) Rp 8.000.000. Dengan asumsi harga jual seperti tersebut di atas, maka dapat dihitung proyeksi pendapatan per tahun seperti disajikan pada Tabel 5. 
Tabel 4. Biaya produksi dan harga pokok produksi pengeringan kayu Table 4. Production cost and cost of production of wood drying

\begin{tabular}{|c|c|c|}
\hline No. & Uraian (Description) & $\begin{array}{l}\text { Biaya produksi } 304 \mathrm{~m}^{3} \\
\text { kayu jati kering (Production } \\
\text { cost of dried teak), Rp }\end{array}$ \\
\hline $\mathbf{A}$ & Biaya tetap (Fixed cost) & \\
\hline 1 & Sewa tanah (Land rent) & 1.000 .000 \\
\hline 2 & $\begin{array}{l}\text { Penyusutan alat/mesin dan bangunan (Depreciation of } \\
\text { equipment/machineries and building), } 10 \text { tahun (10 years) }\end{array}$ & 7.463 .500 \\
\hline 3 & $\begin{array}{l}\text { Pemeliharaan tungku/kipas, dan lain-lain } \\
\text { (Maintenance of stoves/fans,etc), 10\% dari harga dasar } \\
(10 \% \text { of basic price })\end{array}$ & 4.990 .000 \\
\hline 4 & $\begin{array}{l}\text { Bunga bank (Bank interest), } 15 \% \text { dari investasi } \\
(15 \% \text { of investment) }\end{array}$ & 11.195 .250 \\
\hline \multirow[t]{2}{*}{5} & Gaji operator pengeringan (Drying operator salary) & 12.000 .000 \\
\hline & Jumlah biaya tetap (Total of fixed cost), A & 36.648 .750 \\
\hline B. & Biaya tidak tetap (Variable cost) & \\
\hline 1. & Kayu jati basah (wet teak wood) & 3.200 .000 .000 \\
\hline 2. & Limbah kayu untuk bahan bakar (Wood waste for fuel) & 3.900 .000 \\
\hline 3. & $\begin{array}{l}\text { Listrik untuk penggerak motor kipas/blower } \\
\text { (Electricity for driving fan/ blower engine) }\end{array}$ & 5.000 .000 \\
\hline \multirow[t]{4}{*}{5.} & Lain-lain (Others related) & 6.000 .000 \\
\hline & Jumlah biaya tidak tetap (Total of variable cost), B & 3.214 .900 .000 \\
\hline & Jumlah biaya produksi (Total of production cost), $\mathrm{A}+\mathrm{B}$ & 3.251 .548 .750 \\
\hline & $\begin{array}{l}\text { Harga pokok produksi kayu jati kering } / \mathrm{m}^{3} \\
\left(\text { Cost of production of dried jati wood } / \mathrm{m}^{3}\right)\end{array}$ & $\left.10.695 .884 / \mathrm{m}^{3} 1\right)$ \\
\hline
\end{tabular}

Keterangan (Remark) : Diperoleh dari jumlah biaya produksi (Obtained from production cost total)/304 $\mathrm{m}^{3}$ $\left[80 \% \times 380 \mathrm{~m}^{3}\right.$ kayu basah (green wood) $]$

\section{Kelayakan finansial}

Untuk mengetahui kelayakan finansial dari pemanfaatan mesin pengering digunakan analisa BEP, NPV dan IRR. Break Event Point (Titik impas) adalah kondisi kegiatan perusahaan dalam keadaan tidak memperoleh keuntungan tetapi juga tidak menderita kerugian. Dengan asumsi harga jual kayu jati kering Rp $11.000 .000 / \mathrm{m}^{3}$ dan discount factor 15\%, maka BEP tercapai pada produksi sebesar 86,3 $\mathrm{m}^{3}$; NPV + Rp 374.245.458 dan IRR sebesar $80 \%$. Hasil analisis kelayakan finansial disajikan pada Tabel 6 . 
Tabel 5. Proyeksi pendapatan produksi kayu jati kering menggunakan mesin tipe-I (SC+TI)

Table 5. Projected revenue of dried jati wood production using type-I $(S C+T I)$ machine

\begin{tabular}{|c|c|c|}
\hline $\begin{array}{c}\text { Tahun ke } \\
\text { (Consecutive year) }\end{array}$ & $\begin{array}{c}\text { Laba kotor (Gross profit) } \\
\text { Rp }\end{array}$ & $\begin{array}{c}\text { Laba bersih (Net profit) } \\
\text { Rp }\end{array}$ \\
\hline 1 & $17.816 .2641)$ & 15.143 .824 \\
2 & 92.451 .264 & 78.583 .574 \\
3 & 92.451 .264 & 78.583 .574 \\
4 & 92.451 .264 & 78.583 .574 \\
5 & 92.451 .264 & 78.583 .574 \\
6 & 92.451 .264 & 78.583 .574 \\
7 & 92.451 .264 & 78.583 .574 \\
8 & 92.451 .264 & 78.583 .574 \\
9 & 92.451 .264 & 78.583 .574 \\
10 & 92.451 .264 & 78.583 .574 \\
\hline Rata-rata (Average) & 849.877 .640 & 722.395 .994 \\
\hline
\end{tabular}

Keterangan (Remarks): Laba bersih (Net profit) = Laba kotor dikurangi pajak sebesar 15\% (Gross profit substracted by $15 \%$ tax).

Tabel 6. Kelayakan finansial mesin pengering tipe-I (SC+TI) Table 6. Finansial feasibility of type-I $(S C+T I)$ drying machine

\begin{tabular}{|c|c|c|}
\hline No. & Analisis (Analysis) & Nilai (Value) \\
\hline 1. & $\operatorname{BEP}\left(\mathrm{m}^{3}\right)$ & 86,3 \\
2. & $\operatorname{NPV}(\mathrm{Rp})$ & +374.245 .458 \\
3. & $\operatorname{IRR}(\%)$ & 80 \\
\hline
\end{tabular}

Keterangan (Remarks) $:$ BEP $=$ Titik impas $($ Break even point); NPV $=$ Nilai sekarang neto (Net present value); IRR = Internal rate of return

\section{KESIMPULAN DAN SARAN}

Dari hasil percobaan pengeringan kayu jati dengan menggunakan mesin pengering tenaga surya tipe SC+TI dengan bahan bakar tungku dari limbah penggergajian, diperoleh kesimpulan, sebagai berikut:

1. Daya tampung ruang pengering SC+TI untuk setiap periode pengeringan sekitar $19 \mathrm{~m}^{3}$ kayu basah. Suhu rata-rata harian dari panas surya yang diterima dalam ruang pengering berkisar antara $40-50^{\circ} \mathrm{C}$, sementara kebutuhan suhu untuk pengeringan kayu jati berkisar antara $45-70^{\circ} \mathrm{C}$. Kekurangan panas, terutama pada malam hari atau setelah kadar air kayu 
mencapai 30\%, disuplai dari tungku bakar. Bahan bakar tungku menggunakan limbah kayu berupa kulit, sebetan dan potongan ujung dolok yang tidak bisa dimanfaatkan lagi, hasil dari kegiatan di lokasi penggergajian sendiri.

2. Untuk mengeringkan sortimen kayu jati basah dengan kadar air rata-rata 50\% sampai mencapai kadar air 10\% memerlukan waktu rata-rata 13 hari dan menghasilkan rendemen kayu kering sekitar $80 \%$. Sisa yang 20\% akan dijadikan sortimen yang lebih pendek/ sempit untuk bahan baku produk yang sesuai. Konsumsi limbah kayu untuk bahan bakar tungku pada setiap periode pengeringan sekitar $8 \mathrm{~m}^{3}$.

3. Investasi pendirian unit pengeringan memerlukan biaya sebesar Rp74.635.000. Biaya produksi setahun (produksi $304 \mathrm{~m}$ ) adalah Rp 3.251.548.750, sehingga harga pokok produk Rp 10.695.884/m³.

4. Analisis kelayakan finansial pemanfaatan mesin pengering menunjukan dengan harga jual kayu jati kering Rp 11.000.000/ $\mathrm{m}^{3}$ BEP tercapai pada produksi sebesar $86,3 \mathrm{~m}^{3}$, NPV Rp +374.245 .458 dan IRR 80\%. Hasil ini menunjukkan bahwa mesin pengering tersebut layak untuk dioperasikan.

5. Mengingat, investasi mesin pengering yang ada di pasaran saat ini masih mahal dan diproduksi untuk skala besar, maka disarankan perlu dilakukan sosialisasi penerapan mesin pengering SC+TI di tingkat industri kecil-menengah (UKM) yang memiliki dana dan SDM yang terbatas.

\section{DAFTAR PUSTAKA}

Anonim. 1994. Standard methods of testing small clear specimens of timber. American Standard Institution (ASI). In Annual Book of ASTM Standard vol. 4, sec.4. Construction. Philadelphia, USA.

.1997/1998. Forestry Statistics of Indonesia 1997/1998. Ministry of Forestry and Estate Crops. Jakarta.

Armstrong, J.P. 2005. Solar drying basic. Wood Industry Fact Sheet. West Virginia University, Extension Service. 1-4 pp.

Abdullah, K. 1991. Energi dan listrik pertanian. Laporan kerjasama dengan JICA. Institut Pertanian Bogor (Sirkulasi terbatas).

2003. Fish drying using solar energy. The combination of solar and biomass energy in wood drying. Proceeding of Regional Workshop on Drying Technology: The Third Seminar and Workshop, 21-25 July 2003, Salak Hotel, Bogor. 122-140 pp. ASEAN Subcommittee on Non-Conventional Energy Research.

Basri, E., Gusmailina, dan T. Priadi. 2003. The combination of solar and biomass energy in wood drying. Proceeding of Regional Workshop on Drying Technology: The Third Seminar and Workshop, 21-25 July 2003, Salak Hotel, Bogor. 1-8 pp. ASEAN Subcommittee on Non-Conventional Energy Research. 
, dan N. Hadjib. 2004. Hubungan sifat dasar dan sifat pengeringan lima jenis kayu andalan Jawa Barat. Jurnal Penelitian Hasil Hutan 22 (3): 155-166. Pusat Litbang Teknologi Hasil Hutan, Bogor.

Candra, S.A. 1996. Pengeringan kayu bayur dengan alat pengering greenhouse berpenyerap panas plat hitam dan menggunakan batu bara sebagai suplemen energi. Fakultas Teknologi Pertanian IPB, Bogor. Skripsi (Tidak diterbitkan).

Howe, J.W. 1977. Response to Al Noor Kassum report about the utilization of solar energy radiation in Tanzania. Workshop on Solar Energy for the Villages of Tanzania, August 11-19, 1977 in Dar es Salaam. 68-72 pp. Tanzania National Scientific Research Council.

Riyanto, B. 2005. Dasar-dasar Pembelanjaan Perusahaan. BPFE-Yogyakarta.

Roliadi, H dan R.A. Pasaribu. 2005. Uji coba mesin serpih mudah dipindahkan untuk produksi serpih dari limbah industri penggergajian kayu. Jurnal Penelitian Hasil Hutan 23 (3): 219-227. Pusat Litbang Hasil Hutan. Bogor.

Terazawa, S. 1965. An easy methods for the determination of wood drying schedule. Wood Industry Vol.20 No.5. Wood Technological Association. Japan.

Williams, J.R. 1977. Present status of technology for solar-thermal applications. Workshop on Solar Energy for the Villages of Tanzania, August 11-19, 1977 in Dar es Salaam. Pp. 92118. Tanzania National Scientific Research Council. 